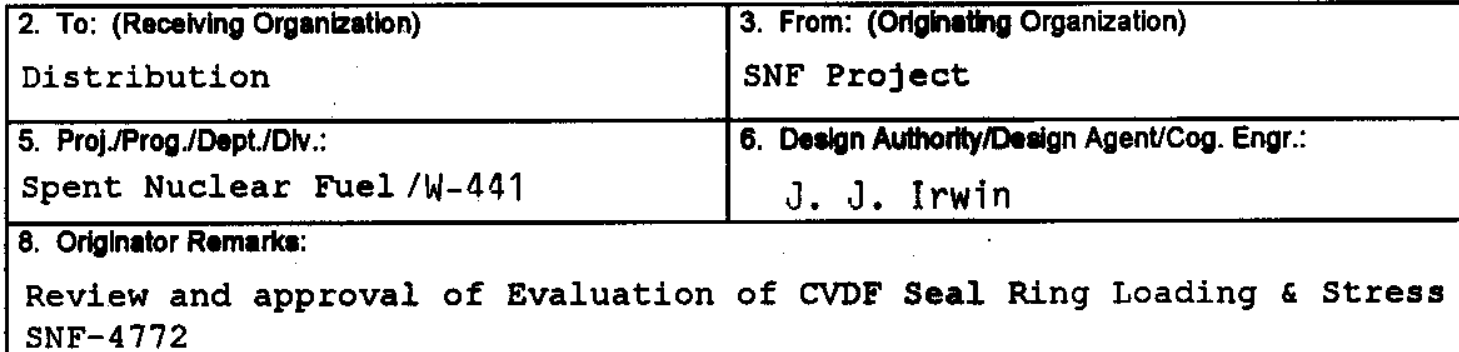
SNF- 4772

11. Recelver Remarks: 11A. Design Baceline Document? () Yes No

\section{DATA TRANSMITTED}

15

\begin{tabular}{|l|l|}
\hline $\begin{array}{c}\text { (A) } \\
\text { Item } \\
\text { No. }\end{array}$ & (B) Document/Drawing No. \\
\hline 1 & SNF-4772 \\
\hline & \\
\hline & \\
\hline & \\
\hline & \\
\hline & \\
\hline
\end{tabular}

\begin{tabular}{|l|l|}
\hline $\begin{array}{l}\text { (C) Sheet } \\
\text { No. }\end{array}$ & $\begin{array}{c}\text { (D) Rov. } \\
\text { No. }\end{array}$ \\
\hline & 0 \\
\hline & \\
\hline & \\
\hline & \\
\hline
\end{tabular}

(E) THe or Description of Data Tranamitted

Evaluation of Cold Vacuum Drying Facility seal Ring Loading and Stress
4. Related EDT No.:

N/A

7. Purchase Order No.:

$\mathrm{N} / \mathrm{A}$

9. Equlp./Component No.:

$\mathrm{N} / \mathrm{A}$

10. Syctem/Bldg./Facility:

N/A

12. Major Asem. Dwg. No.:

N/A

13. Permit/Permik Application No.:

N/A

14. Required Response Date:
16.

\begin{tabular}{|c|}
\hline Approval Dedignator (F) \\
\hline E, S, Q D OR N/A \\
(See'WHC-CM-3-5, \\
Sec. 12.7) \\
\hline
\end{tabular}

17.

Rea-
Reaseon for Tranemiltal (G)

4. Reviow

5. Post-Review

B. Dlet. (Recolot Acknow. Roquired)

KEY GICNATUREDISTRIBUTION (See Approval Deasmotor for required signatures)

\begin{tabular}{|ll|}
\hline \multicolumn{3}{|c|}{ Dispostion (H) \& (I) } \\
\begin{tabular}{|ll} 
1. Approved & 4. Revlowed no/comment \\
2. Approved w/comment & 5. Reviowed w/comment \\
3. Disapproved w/comment & B. Recelpt acknowlodged \\
\hline TION &
\end{tabular}
\end{tabular}

(F)

(G)

\begin{tabular}{|c|c|}
\hline$(F)$ & $(G)$ \\
\hline $\begin{array}{c}\text { Approval } \\
\text { nator }\end{array}$ & $\begin{array}{c}\text { Reason } \\
\text { or Trane- } \\
\text { mittal }\end{array}$ \\
\hline
\end{tabular}

\begin{tabular}{|c|c|c|c|c|}
\hline $\begin{array}{l}\text { (G) } \\
\text { Rea- } \\
\text { son }\end{array}$ & Disp. & (K) Signature (L) Date (M) MSIN & $\begin{array}{l}\text { (G) } \\
\text { tod } \\
\text { mod }\end{array}$ & Disp. \\
\hline 1 & & Deslon Authority JJ I rwin & 3 & 6 \\
\hline & & Design Agent & 3 & \\
\hline & & Cog. Eng.' & 3 & \\
\hline 1 & L & Cog. Mgr. KA Boes $t$ & 3 & \\
\hline 1 & 1 & 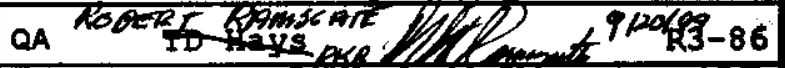 & 3 & \\
\hline 1 & 1 & Safoty $^{N}$ JR Brehm & 3 & \\
\hline 3 & & Env. CVD Fileb & 3 & \\
\hline
\end{tabular}

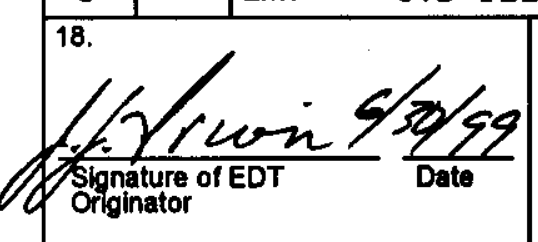

(J) Name

CR Miska

WC Alaconis

$R$ Whitehurst CC Pitkoff

s Brisbin

D Chenault Project Files

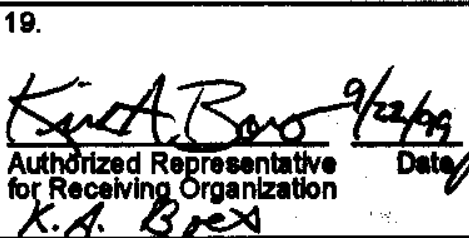
20.

BD-7400-172-2 (10/97)

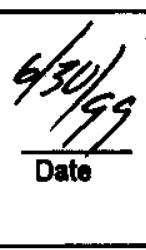

(K) Signature

(L) Date (M) MSIN $C R$ th 962/9 R3-86 R3-86 R3-86 R3-86 R3-86 R3-86 R3-11
21. DOE APPROVAL (if required) Ctrl No.

Approved

Approved w/comments

Disapproved w/comments 


\title{
EVALUATION OF COLD VACUUM DRYING FACILITY SEAL RING LOADING AND STRESS
}

\author{
B. A. Crea \\ Numatec Hanford Corporation \\ Richland, WA 99352 \\ U.S. Department of Energy Contract DE-AC06-96RL13200
}
EDT/ECN: $625668 \quad$ UC: 2000
Org Code: $83300 \quad$ Charge Code: 105559
B\&R Code: EW04J1110 Total Pages: 14

Key Words: seal ring, Multi-Canister Overpack, stress, cask, tempered water

Abstract: The loads and resulting stresses in the seal ring are calculated and compared to the allowables for the service from ASME Boiler and Pressure Vessel code.

TRADEMARK DISCLAIMER. Reference hereln to any specific commercial product, process, or service by trade nume, trademark, manufecturer, or othenwise, does nof necsearly constitute or imply the endoreement, recommendation, or tavoring by the United States Government or any agmoy thereof or its contractors or subcontractors.

Printed in the United States of America. To obteln coplese of this document, contact: Document Control Services. P.O. Box 850, Malletop H6-08, Richland WA cess2, Phon (509) 372-2420; Fax (509) 376-4989.

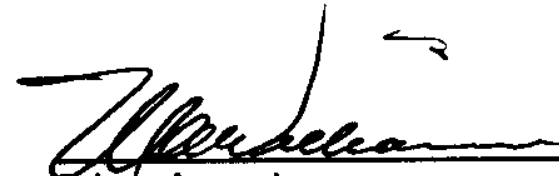

Robace Approval

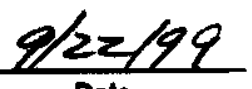

Date

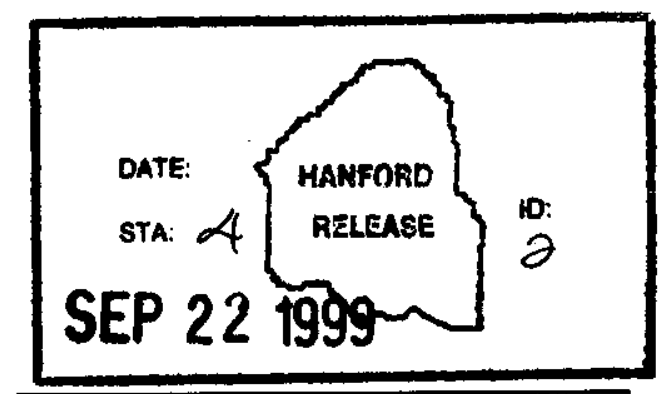

Release Stamp 
SNF-4772

Revision 0

\section{EVALUATION OF COLD VACUUM DRYING FACILITY SEAL RING LOADING AND STRESS}

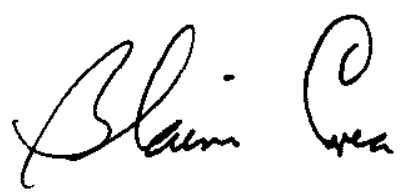

B. A. Crea

Numatec Hanford Corporation

June 1999 
A stress analysis of the Cold Vacuum Drying Facility seal ring has been done to show that the stress levels under loading caused by process malfunctions were acceptable. The loading that the seal ring was subjected to is the unbalanced pressure load of the multi-canister overpack (MCO). Due to the design of the seal ring-MCO-cask interface, the pressure against the MCO at the bottom of the seal ring acts to eject the MCO from the cask as a piston from a cylinder. One of the features of the seal ring is a retention lip to ensure that the MCO is retained in the cask under conditions that could cause its ejection. The seal ring was analyzed for the stresses due to these loads. The stresses were found to be low with respect to the allowable stress value for the material of construction as defined in the ASME Boiler and Pressure Vessel Code Section VIII. In addition, the bolt preload required to ensure that the bolts that secure the seal ring to the cask would be loaded only in tension was defined and the amount of rotation required to achieve that preload is calculated. These calculations as well as excerpts from the MCO design report and a drawing of the seal ring as analyzed are included. The material callout on the general arrangement drawing forms the basis for definition of the maximum allowable stress values taken from the ASME Boiler and Pressure Vessel Codes. 

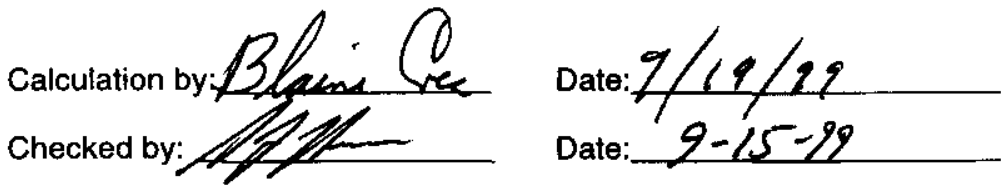

Analysis of the cask/MCO seal ring for normal loadings and also the upset loadings caused by the MCO load against the restraining lip.

References: ASME Boiler and Pressure Vessel Code Section VIII and II 1998

Roarks's Formulas for Stress and Strain, 6 th Edition, Warren C Young, 1989

First define the normal tempered water system pressures to evaluate the loading condition(s) that the seal ring may be subject to.

Based on the loop calculations done by Merrick (CVD-1) the tempered water system gauge pressures at the top of the cask/MCO are slightly negative under normal operation, since the air space in the tempered water storage tank provides the atmospheric reference for the system and the flow losses in the plpe and hose from the top of the cask/MCO are slightly less than the head difference due to height betwoen the top of the cask/MCO and the inlet nozzle to the tank. The pressure gain from the bottom of the cask to the top is around 5 psid based on the same calculation, most of which is the required to overcome the 12 foot elevation change.

The above described loading condition provides no challenge to the seal ring integrity, and though It may fall outside the definition of normal service the seal ring has been designed to act as a restraining mechanism if the valve in the outlet line (GOV 1*14) should inadvertently become closed during normal operation. When this happens the whole system can be assumed to be pressurized at the shutoff head of the tempered water system pump (TW-P-3*14). The nominal value of thls parameter is 118 feet of head based on the pump curve in CVD-1, Note that the max size impeller is specified.

$$
P \max :=118 \cdot 4335 \quad P \operatorname{Pmax}=51.153 \text {. psig }
$$

The design basis pressure is specified as $60 \mathrm{psig}$ for the annulus between the cask and the MCO, however, this is based on the external pressure rating of the MCO rather than any consideration of the pump capablity. A value of 55 psig will be used as a design basis, to provide a reasonable margin for any credible variation in pump performance.

$$
\text { Pmax := } 55 \text { psig }
$$

The differential pressure acts on the upper sectlon of the MCO where the diameter of the MCO is increased from the nominal value of 24 inches to a diameter of 25.31 Inches. This pressure acts over this area to provide an upward force that will tend to lift the MCO out of the cask. The total upward load due to this pressure ls:

$$
\text { Dmco }:=25.3 \quad \text { Amco }:=\frac{\pi}{4} \cdot\left(\text { Dmco }^{2}\right) \quad \text { Fp }:=\text { Pmax.Amco } \quad F p=27649.903 \quad \text { Pounds }
$$

There is also a buoyancy load associated with the water in the cask that is displaced by the MCO. About 158 inches of the total length of 160 inches can be considered to be submerged in the water.

$$
\text { Lbmco }:=158 \quad \mathbf{F b}:=62.4 \cdot\left(\frac{\text { Lbmco } \cdot \text { Amco }}{1728}\right) \quad \mathbf{F b}=2868.328 \quad \text { pounds }
$$

There is also a pressure load that acts between the top of the cask and the bottom of the seal ring, and a load due to the pressure of the inflatable seal. While these loads are applied at a point closer to the holdown bolts than the loads due to the MCO restraint loads, and so will produce less bending moment and thus 8 tress in the plate than is produced by the loads closer to the center, nevertheless they will be applied at the same point in order to simplify the analysis. 

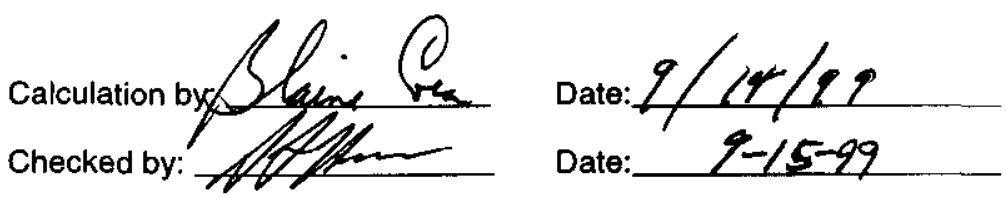

The pressure acts over an area that is bounded on the inside by the head of the MCO which has a diameter of $\mathbf{2 5 . 3 0}$ inches and on the outslde by the inflatable seal groove which has a diameter of 27.31 inches. The inflation pressure for the inflatable seals is 30 psi and will be assumed to act over an annular ring that has a diameter 27.93 inches and is .625 inches wide. The total load due to these pressures ls:

$$
\begin{aligned}
& \text { Fpress }:=\left[P \max \cdot \frac{\pi}{4} \cdot\left(27.31^{2}-25.3^{2}\right)\right]+30 \cdot 27.93 \cdot \pi \cdot 625 \quad \text { Fpress }=6213.116 \quad \text { pounds } \\
& \begin{array}{ll}
\text { Fup }:=F p+F b+F p r e s s & \text { Fup }=36731.348 \quad \text { pounds }
\end{array}
\end{aligned}
$$

The dead weight of the MCO and contents acts to resist this upward load. For the purposes of this analysis the minimum credible welght ls desired. It seems to be unreasonable to use a weight that is less than that of a dry, nominally loaded MCO. Note that for this loading to occur there is already one possible but not probable occurrence i.e. GOV-1*14 is closed when it shouldn't be. For any occasions when a less than nominally loaded MCO is present administrative controls will be implemented to ensure that the discharge from the seal ring to the tempered water storage tank won't be obstructed.

Use the 16278.3 pound value for the average dry MCO $-2 \sigma$ in condition 2.

$$
\text { Fdown }:=16278.3 \quad \text { Pounds } \quad F:=\text { Fup - Fdown } \quad F=20453.048 \quad \text { pounds }
$$

The governing code is ANSI B31.3, Process Piplng. Reference is made therein to the use of Section VIII of the ASME Boiler and Pressure Vessel Code, Specifically Section UG-34.

The seal ring construction method and material is specified on the drawing as a forging based on stock that meets either ASTM A240 or ASTM A479 requirements and qualifies as a 300 serles Stainless Steel. While there are numerous entries in the properties section of the ASME Boiler and Pressure Vessel Code that meet these requirements the lowest strength one has an allowable stress (Sa) at 200 of of 16,700 psi. This is taken from Section Il; part D; Table 1a; page $90,91,92$; Lines 5 or 23. There le one lower strength value recommended for service where deformation may be a problem l.e. low temperature creep may lead to sealing problems. This isn't judged to be a concern for this application and so this value will be used.

First do the blind flange equation from ASME section 8 UG-34 and compare the results with a similar case in Roark. This "code case" solution has many features in common with the case under consideration. Comparison of the resulte will be done to ensure that factors due to experience and higher order effects that are often incorporated in the ASME formulas are accounted for in this analysis.

Use D of 32.81 and $t$ of .75 as the critical section, From Figure UG-34 (p) C is .25

$$
\begin{array}{lll}
\text { tf }:=.75 \text { inches } \quad \text { df }:=32.81 \text { inches Peq }:=\frac{F}{\frac{\pi}{4} \cdot\left(\text { df }^{2}\right)} & \text { Peq }=24.191 \quad \text { psi } \\
\text { oasme }:=\frac{.25 \cdot \text { Peq }}{1.0} \cdot\left(\frac{\mathbf{d f}}{\mathbf{t f}}\right)^{2} & \text { oasme }=11574.057
\end{array}
$$

Stress in a circular plate with the edge fixed (Table 24 case 10b Roark). This case will be used to compare the result presented in Roark with the requirement of the ASME Code for the blind flange case.

First define the functions required by this approach as well as poisson's ratio and the elastic modulus 

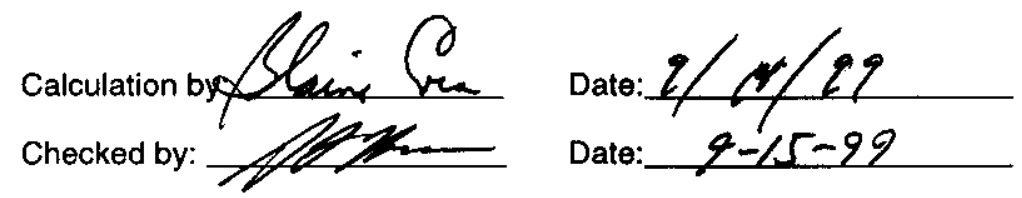

$$
\begin{aligned}
& \begin{array}{lll}
\sigma \mathbf{m}(\mathbf{m}, \mathbf{t}):=6 \frac{\mathbf{m}}{\mathbf{t}^{2}} & \text { poisson's ratio } v:=.3 & \text { modulus } \mathrm{Em}:=26 \cdot 10 \\
\mathbf{a}:=\frac{\mathrm{df}}{2} & \mathbf{q}:=\text { Peq } & \text { Mc }:=\frac{\mathbf{q} \cdot \mathbf{a}^{2} \cdot(1+v)}{16}
\end{array} \\
& \sigma t:=\sigma m(M c, t f) \quad \text { Mra }:=\frac{-q \cdot a^{2}}{8} \text {. } \\
& \text { ot }=5642.353 \quad \text { or }=-8680.543 \\
& \sigma r:=\sigma m(\text { Mra }, t f) \\
& \text { oroark := if }(\mid \text { or }|s| \text { ot }|,| \text { ot }|,| \text { or } \mid) \quad \frac{\text { oasme }}{\text { oroark }}=1.333
\end{aligned}
$$

So based on this it appears that the ASME Boller and Pressure vessel code applies a factor of 1.333 to the stress equation that is developed from the classical solution to the circular plate with uniform load to arrive at the design equation for the blind flange. Since the case we have is similar in many respects albeit the geometry of the seal ring more nearly matches the geometry associated with the results presented in:

Table 24 case $1 \mathrm{~b}$ or $1 \mathrm{e}$ or $1 \mathrm{f}$ in Roark. The difference between case $1 \mathrm{~b}$ and case $1 \mathrm{f}$ is the degree of fixity provided by the holddown bolts. Case $1 \mathrm{~b}$ is representative of a condition where the holdown bolts provide no moment resisting capability at the edge of the ring. This may be a bounding value for a section that is between two bolts, i.e. there are 3 bolts at 1200 spacing and the edge moment may not be totally restrained in the section between them. Case if is representative of the condition at the azimuthal location of the holdown bolt. The difference between cases $1 e$ and $1 f$ lies in the degree of fixity provided by the central portion of the seal ring. So solve this for these cases and ensure that the results from all are acceptable. Note that the large sectional dimension of the ring in the center makes the results from case $1 \mathrm{~b}$ and $1 f$ at the inner radius very conservative.

Consider that the effective outer radius (where moments and stresses will be evaluated) is to the outer edge of the $3 / 4$ inch thick section. The annular ring that contains the hold down bolt circle is $\mathbf{1 . 8 1}$ inches thick and so has over twice the section thickness and effectively less than $25 \%$ of the stress for the same moment. The inner radius will be set to the inner diameter of the central stiff section of the seal ring. This inner diameter is selected from the standpoint of creating a reasonably conservative calculation, since the smaller the inner diameter the higher the stress, all other factors held constant.

\section{Hold down bolt circle}

Transition diameter between the thicker outer ring and the $3 / 4$ in thick section

Inner diameter of central sect

$$
\text { Db := } 36.44 \quad \text { inches }
$$

$$
\mathbf{D t}:=32.8 \quad \text { inches } \quad \mathbf{a}:=\frac{\mathrm{Dt}}{2}
$$

$$
\text { DI }:=26.68 \quad \text { inches } \quad \mathbf{b}:=\frac{\mathbf{D i}}{2} \quad \frac{\mathbf{b}}{\mathbf{a}}=0.813
$$

Evaluate the general plate functions and constants needed to solve these cases $\left(L_{6}, L_{9}, C_{4}, C_{5}, C_{7}, C_{8}\right)$. Note that for these cases $r_{0}=b$

$$
\mathbf{L}_{\mathbf{6}}:=\frac{\mathbf{b}}{4 \cdot \mathbf{a}} \cdot\left[\left(\frac{\mathbf{b}}{\mathbf{a}}\right)^{2}-1+2 \cdot \ln \left(\frac{\mathbf{a}}{\mathbf{b}}\right)\right] \quad \mathbf{L}_{\mathbf{9}}:=\frac{\mathbf{b}}{\mathbf{a}} \cdot\left[\frac{1+v}{2} \cdot \ln \left(\frac{\mathbf{a}}{\mathbf{b}}\right)+\frac{(1-v)}{4} \cdot\left[1-\left(\frac{\mathbf{b}}{\mathbf{a}}\right)^{2}\right]\right]
$$



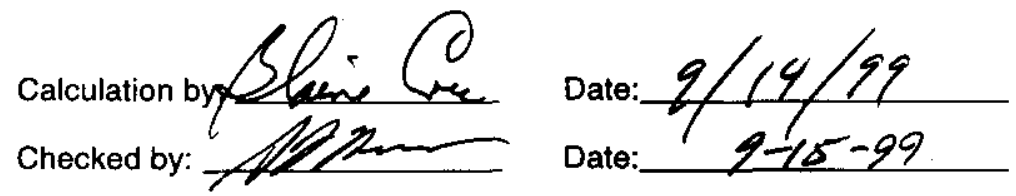

$$
\begin{array}{ll}
\mathbf{C}_{4}:=\frac{1}{2} \cdot\left[(1+v) \cdot \frac{\mathbf{b}}{\mathbf{a}}+(1-v) \cdot \frac{\mathbf{a}}{\mathbf{b}}\right] & \mathbf{C}_{5}:=\frac{1}{2} \cdot\left(1-\left(\frac{\mathbf{b}}{\mathbf{a}}\right)^{2}\right] \\
\mathbf{C}_{7}:=\frac{1}{2} \cdot\left(1-v^{2}\right) \cdot\left(\frac{\mathbf{a}}{\mathbf{b}}-\frac{\mathbf{b}}{\mathbf{a}}\right) & \mathbf{C}_{\mathbf{8}}:=\frac{1}{2} \cdot\left[1+v+(1-v) \cdot\left(\frac{\mathbf{b}}{\mathbf{a}}\right)^{2}\right]
\end{array}
$$

Define the plate constant

$$
\text { D : }=\frac{\mathbf{E m} \cdot \mathbf{t}^{3}}{12 \cdot\left(1-v^{2}\right)}
$$

Define the line load needed for these formulations

$$
\mathbf{w}:=\frac{\mathbf{F}}{(2 \cdot \boldsymbol{\pi} \cdot \mathbf{b})}
$$

$$
\begin{array}{lll}
\text { Case1b } & \text { Mrbib }:=\frac{\mathbf{w \cdot a \cdot \mathbf { L } _ { \mathbf { g } }}}{\mathbf{C}_{\mathbf{8}}} & \operatorname{Mrb1b}=714.299 \\
\operatorname{\sigma in1b}:=\boldsymbol{\sigma m}(\text { Mrb1b }, \mathbf{t}) & & \operatorname{\sigma in1b}=7619.191
\end{array}
$$

Calculate the rotation at the edge of the plate that would occur if the bolts were merely used to provide holdown force and weren't torqued down, or were loose.

$$
\begin{aligned}
& \theta a 1 b:=\frac{w \cdot a^{2}}{D} \cdot\left(C_{5} \cdot \frac{L_{9}}{C_{8}}-L_{6}\right) \quad \quad \theta a 1 b=0.0009809 \quad \text { radians } \\
& \text { Case 1e } \quad \text { Mra1e }:=-\mathbf{w} \cdot \mathbf{a} \cdot\left(\mathbf{L}_{\mathbf{9}}-\frac{\mathbf{C}_{\mathbf{7}} \cdot \mathbf{L}_{\mathbf{6}}}{\mathbf{C}_{\mathbf{4}}}\right) \quad \text { Mra1e }=-617.715 \\
& \text { oout1e }:=\sigma \mathbf{m}(\text { Mra1e }, \mathrm{tf}) \quad \text { oout1e }=-6588.964 \\
& \text { Case } 1 f \\
& \text { Mra1f }:=-w \cdot a \cdot\left(L_{9}-\frac{C_{8} \cdot L_{6}}{C_{5}}\right) \quad \text { Mra1f }=-313.05
\end{aligned}
$$

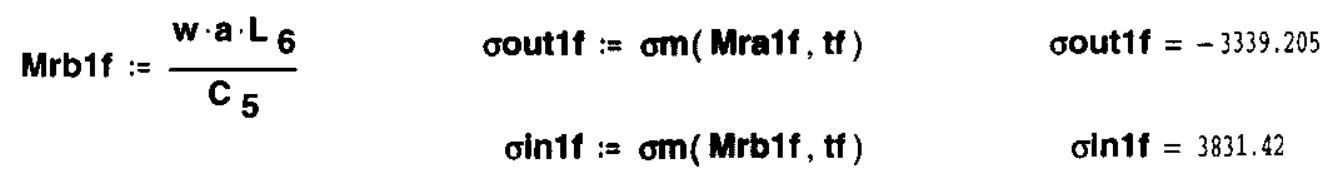

The margin to the code allowable based on the comparison between code calculated stresses, The largest stress from the cases above, and the bumpup factor derived from the comparison between the code formula and the analytical formula for the blind flange is:

$$
\frac{16700}{\operatorname{coin1b} \mid \cdot 1.333}=1.644 \quad \text { Therefore the Margin of Safety is } .644
$$

In conclusion the stress which is based on a case that is conservative from the standpoint of edge restraint, and which has the hlghest stress of all the cases considered has a factor of safety of 1.644 based on the code allowable for normal operation. 

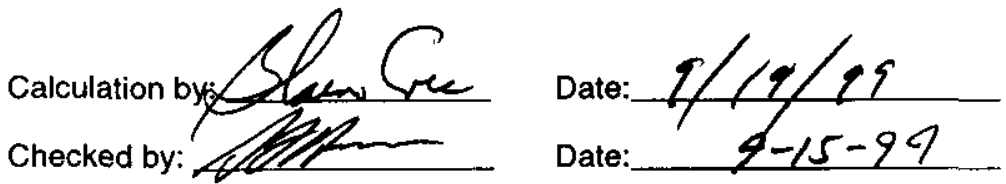

\section{Holdown Bolt Preload and Plate Edge Moment}

$1 / 3$ of the total uplift force is resisted by each bolt. Some loading may also be induced in the bolts due to the plate edge moment as tabulated above. While a significant fraction of the plate edge moment will be resisted by the thlcker outer ring that the bolts are seated in a conservative treatment of the required bolt capacity can be achieved by ensuring that the bolts have adequate elongation capability to allow for full rotation of the edge of the ring as if It were unrestrained. Note that the clearance between the body of the bolt and the hole/counterbore provided for the bolts is adequate to preclude the loading of the bolts by a moment due to the rotation of the outer portion of the seal ring.

The bolts are 60 nitronic and have a yield strength of $60 \mathrm{ksi}$. The code allowable for upset type conditions is $80 \%$ of the yield. When torqued to hold down the seal ring they should be torqued to a load that will guarantee that compressive stress will be maintained in the interface between the seal ring and the cask. This will ensure that they won't be placed in a configuration where they will be loaded with a moment.

First calculate the bolt stress due to the upward load only, i.e. what fraction of the bolt's capacity is required merely to prevent the seal ring from moving far enough to break the seal and thus remove the upward force.

$$
\text { Abolt }:=\frac{\pi}{4} \cdot 1.18^{2} \quad \text { Fbolt1 }:=\frac{F}{3} \quad \text { obup }:=\frac{\text { Fbolt1 }}{\text { Abolt }} \quad \frac{\text { obup }}{0.8 \cdot 60000}=0.13
$$

This is $13 \%$ of the bolt's allowable load under upset conditions.

Now calculate the elongation due to unrestrained rotation of the outer section of the seal ring. Assume that the radius of the rotation Is the distance from the outer edge of the seal ring to the center of the bolt.

Based on the bolt detail use 3.75 in as the effective length of the bolt $\quad L b:=3.75$

$$
\Delta \mathrm{Lrot}:=\frac{3.5}{2} \cdot \text { ea1b } \quad \varepsilon \text { rot }:=\frac{\Delta \mathrm{Lrot}}{\mathrm{Lb}} \quad \text { obrot }:=\text { erot } \cdot \mathrm{Em} \quad \text { obrot }=11901.158
$$

If the uplift load and the rotation load are summed it will provide a conservative treatment of the total bolt load.

The margin of safety is: $\quad \frac{.8 \cdot 60000}{\text { obtot }}-1=1.647$

$$
\text { obtot := obrot + obup }
$$

It is generally considered good practice to torque bolts/fasteners to the level required so that they aren't subject to either repetitive stress or placed in bending. The detailed design of this bolting arrangement precludes the possiblilty of inducing a moment in the bolt, and the static nature of the application ensures that under normal operation the total number of load cycles will be the total number of times that the seal ring is used on a cask (on the order of 100-200). It would still seem prudent to torque the seal ring down to the point that any loads due to this upset condition would be absorbed by the seal ring and the cask rather than the bolt, so specify bolt rotation adequate to place compression on the ring and the cask equal to the bolt tensile load created by the upward force and pressure and the unrestrained rotation of the outer portion of the seal ring.

$$
\Delta L \text { pre }:=\frac{\text { Lb. obtot }}{E m} \quad \Delta \text { Lpre }=0.003
$$

The required elongation is 3 mils. Now solve for the rotation required to stretch the boit the appropriate amount. The bolt has threads with a pitch of 6 threads/in so to stretch the bolt one inch requires 6 full rotations.

$$
\Delta \text { Lpre } 6 \cdot 360=5.65
$$

Need to turn the bolt $6^{\circ}$ from snug to apply enough preload to meet the criteria above. 


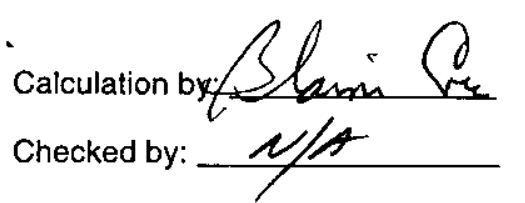

Date: $8 / 25 / 99$

Date:

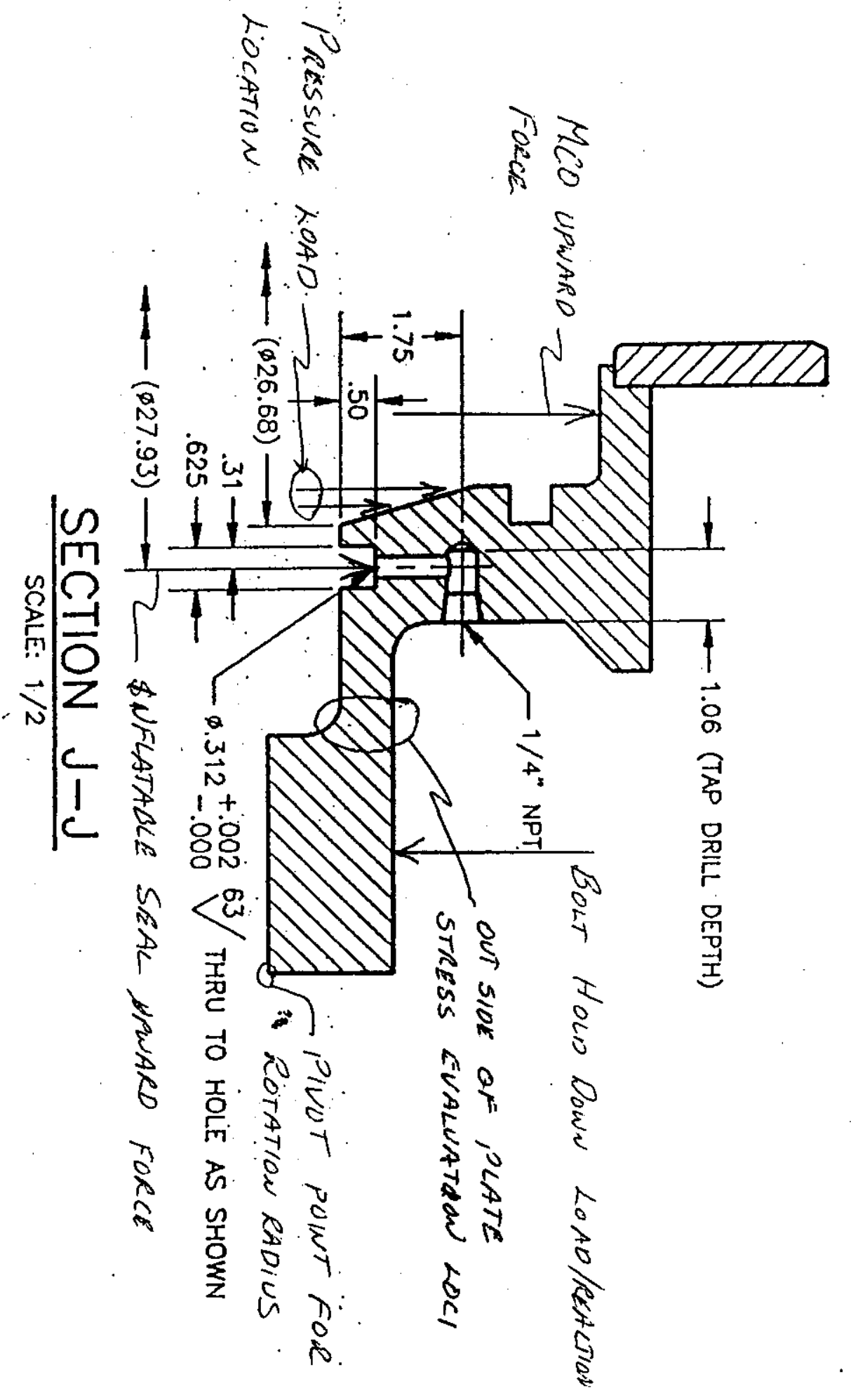



DOC. NO.: HNF-SD-SNF-DR-003, Rev. 2, Appendix 3

Table 1 - Mco Welght Summary

\begin{tabular}{|c|c|c|c|}
\hline MK1A Storage Basket & Empty & 471.95 & 471.95 \\
\hline MK1A Scrap Basket & Empty & 624.61 & 624.61 \\
\hline MK1A Storage Basket & Loaded 48 Fuel Assemblies & 2378.03 & 2378.03 \\
\hline MKIV Scrap Basket & Empty & 432.11 & 432.11 \\
\hline MKIV Storage Basket & Loaded 54 Fuel Assemblies & 3218.34 & 3218.34 \\
\hline MCO & $\begin{array}{l}\text { MCO Condition 1, filled with water and } \\
\text { with five loaded MKIV Storage Baskets. }\end{array}$ & 19064.13 & 19122.14 \\
\hline MCO Condition 2 & $\begin{array}{l}\text { Empty, Shield Plug, Locking Ring with } \\
\text { Screws, Shell, Collar, Guide Cone, } \\
\text { Bottom Plate, Support Plates, Stabilizer } \\
\text { Extension, Internal Filter, Process } \\
\text { Valves, Guard Ring, Guard Plate and } \\
\text { Dip Tube, Dry. }\end{array}$ & 3468.79 & 3598.55 \\
\hline MCO & $\begin{array}{l}\text { MCO Condition 3, filled with water and } \\
\text { with six loaded MK1A Storage Baskets. }\end{array}$ & 18154.10 & 18263.32 \\
\hline MCO & $\begin{array}{l}\text { MCO Condition 3, filled wth water and } \\
\text { with five loaded MKN Storage Baskets. }\end{array}$ & 19983.85 & 20092.45 \\
\hline
\end{tabular}

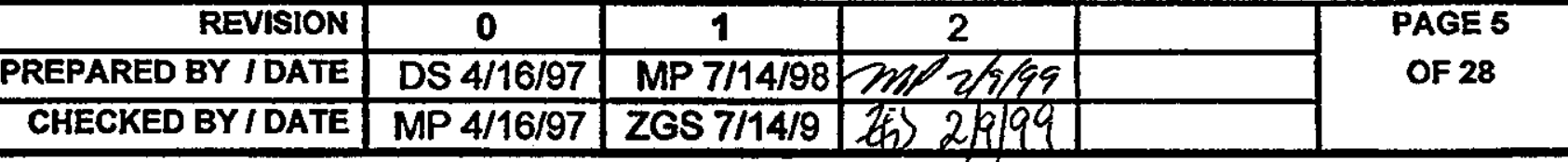


DE\&S Hanford

PAABDNS

PROJECT: MCO Design

FILE NO: KH8009-8-01

\begin{tabular}{|l|l|c|c|}
\hline \multicolumn{3}{|c|}{ Table 2 - MCO Assembled with Canister Cover } \\
\hline \multicolumn{1}{|c|}{ Item } & \multicolumn{1}{|c|}{ Condition } & Nominal Weight (lbs.) & Maximum Weight (lbs) \\
\hline Canister Cover & N/A & 509.31 & 520.83 \\
\hline MCO & $\begin{array}{l}\text { MCO condition 2, Dry, } \\
\text { with six loaded MK1A } \\
\text { Storage Baskets \& } \\
\text { Canister Cover. }\end{array}$ & 18246.28 & 18387.56 \\
\hline MCO & $\begin{array}{l}\text { MCO Condition 2, Dry, } \\
\text { with five loaded MKIV } \\
\text { Storage Baskets \& } \\
\text { Canister Cover. }\end{array}$ & 20069.80 & 20211.08 \\
\hline
\end{tabular}

Notes:

- The Single Pass Reactor (SPR) Fuel basket is a modified version of the Mark 1A fuel basket. A non-structural loading jig replaces the aluminum fuel rack. The fuel elements are stacked 2 to 3 high in each loading position. At the time of this printing (Revision 2) the true weights of the SPR fuel baskets have not been determined. However, the combined weight of the jig and the SPR fuel in the Mark 1A fuel basket is less than the weight of the Mark 1A fuel.

- Revision 2 of this document modifies certain parts of the storage and scrap baskets. Some parts designs were replaced with others, and in most cases the weights do not change. The weights obtained for the fuel baskets in Table 1 were calculated based on nominal dimensions.

- In Table 1, it is assumed that the density of water is $62.3 \mathrm{lb} / \mathrm{ft}^{3}$ (Mark's Handbook, $9^{\text {th }}$ Edition, page $6-10)$ at $70^{\circ} \mathrm{F}$.

- The shield plug assembly consists of the shield plug, the process valves, the guard plate, the guard plate ring, the stabilizer extension, the dip tube and the internal filter. The nominal weight of the shield plug assembly is $1107.24 \mathrm{lb}$. and the maximum weight is $1163.43 \mathrm{lb}$.

\begin{tabular}{|r|c|c|c|c|c|}
\hline REVISION & 0 & 1 & 2 & PAGE 6 \\
OF 28
\end{tabular}




\section{HNF-SD-SNF-DR-003 \\ Rev. 2

Detailed weight calculations for each component of the MCO are provided in Appendix 3. The summary of the expected weights shows that the nominal MCO, without cover, with Mark IA fuel (MCO Condition 2 in Appendix 3), dry, weighs approximately 17,867 lbs. The nominal MCO flooded with Shield Plug, no cover cap or locking ring and with Mark IA fuel (MCO Condition 3 in Appendix 3) weighs approximately 18,264 lbs. The MCO with the Mark IV fuel, dry (MCO condition 2 in Appendix 3) weighs approximately 19,691 lbs. The MCO with the Mark IV fuel, flooded (MCO Condition 3 in Appendix 3), weighs approximately 20,093 lbs. The above weights do not reflect the weight of the scrap baskets. The empty scrap baskets may weigh more than the storage baskets but the loaded weight of the scrap baskets will always be less than that of the storage basket.

\subsubsection{Height of the MCO}

The maximum height of the MCO shall not exceed 160 inches (without final cover cap) at a temperature of $25^{\circ} \mathrm{C}$. This includes any connections or devices integral to the $\mathrm{MCO}$ in facilitating connections to external process equipment and in providing pressure relief. When the final cover cap is welded in place, the maximum height shall not exceed 167.3 inches.

Refer to Section 4, Item 22.

The maximum height of the MCO with the cover cap off is 160 inches. The maximum height of the MCO with the cover cap in place is less than 167.3 inches, as shown in Appendix 1.

\subsubsection{Diameter of the MCO}

The nominal outside diameter of the $\mathrm{MCO}$ is 24-inches. In no case, including post-accident conditions, is the MCO inside circumference below the bottom of the shield plug allowed to exceed 73.04 inches (23.25 inches * pi). The MCO shell is allowed to have a 25.31 -inch maximum as-built OD above the 148-inch elevation measured from the MCO bottom. These dimensional limits are applicable during normal operations and post accident conditions.

Refer to Section 4, Item 23.

The inside circumference below the bottom of the shield plug is maintained to be less than 73.04 inches as shown in Appendix 5 and Appendix 11. These evaluations include the post-level D events as defined in the Performance Specification. The only event that has the potential of any significant distortion of the circumference of the shell is the side drop in the cask and is localized in the area of the collar in the cask. The distortion would be inward (localized denting) and hence the circumference requirement would not be violated.

\subsection{MCO SHELL DESXGN}

The MCO shell is a cylindrical vessel that provides access to its cavity through its top end and receives a shield plug at its top end for closing. The MCO shell has a bottom assembly that 


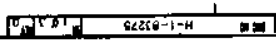
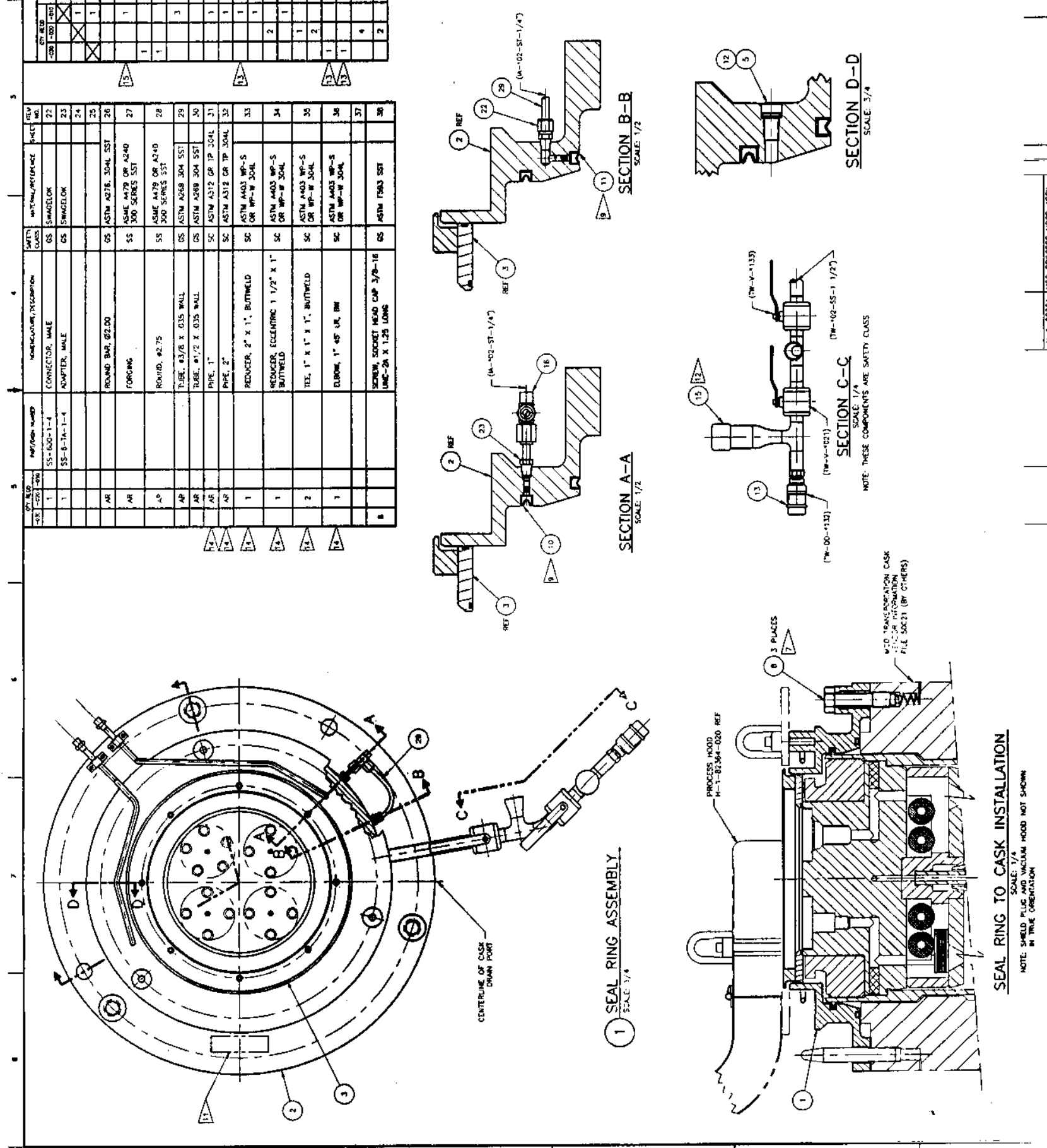


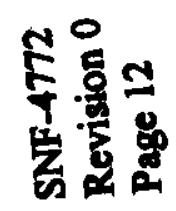

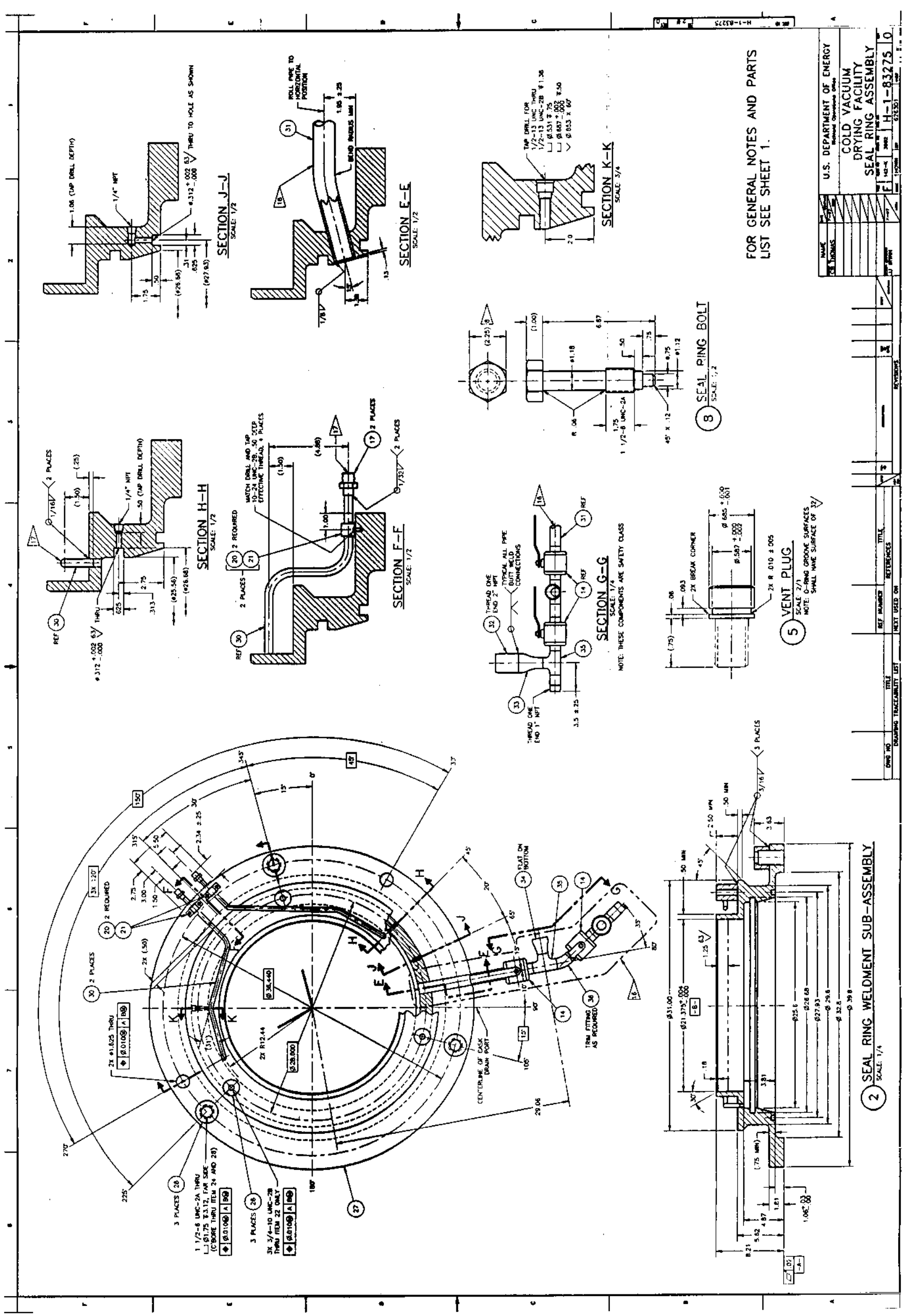

